\title{
Many public urban parks, but who profits from them? The example of Tabriz, Iran
}

\author{
Jürgen Breuste ${ }^{1 *}$ and Akbar Rahimi ${ }^{2}$
}

\begin{abstract}
Introduction: Public urban parks are accessible to everyone in a city. The time people need to reach a public park influences the accessibility of the park. Parks far away from home are less accessible because of time to spend to reach them than those in the neighborhood. Good green urban infrastructure aims to provide different types of parks (by size and structure) to all urban dwellers. The network of parks should allow all inhabitants to have access to parks within close proximity to their residences.

Methods: This paper aims to investigate the accessibility of parks as related to the social status of the inhabitants. This was investigated using the example of a clearly socially stratified city (Tabriz, Iran), in which a part of the urban society (by total number and social status) has better or worse access to urban parks. The example of urban parks shows which services are supplied on site and who the potential users are within an accessible distance. The services are qualified by structural park indicators and quantified by the quantity of these indicators. The distances are calculated on the basis of the size of the parks. Different distance circles around the parks indicate from where most of the users are coming, depending on park category. A quantification of population as related to potential users by social status in different distances to the parks shows the accessibility of parks for different quantities of inhabitants and different social strata. The classification of social status (high, middle, and low) was carried out by General Census of statistical center in 2005, informal settlement project data, statistical blocks data, land price in Tabriz municipality, and master and detailed plan reports.
\end{abstract}

Results: Many households do not enjoy government recommended levels of access to public green spaces in Tabriz, and the results highlight the social segregation in park distribution and their accessibility.

Conclusions: The best parks are located in the high social status areas, and the accessibility is the best among all societal levels.

Keywords: Ecological services; Urban parks; Social status; Park accessibility

\section{Introduction}

A clear focus of urban ecological research is on biodiversity and ecosystem services, energy consumption and sustainability, multifunctional landscapes (design and planning), and carbon footprint for climate change studies (Breuste and Qureshi 2011). Urban ecosystems cover a large proportion of the land surface, or those in which people live at high densities (Pickett et al. 2001). This include also 'green and blue spaces' in urban areas, including parks, cemeteries, yards and gardens, urban allotments, urban forests, wetlands, rivers, lakes, and

\footnotetext{
* Correspondence: juergen.breuste@sbg.ac.at

${ }^{1}$ Research Group for Urban and Landscape Ecology, Department of

Geography and Geology, University of Salzburg, Salzburg, Austria

Full list of author information is available at the end of the article
}

ponds which provide services for urban dwellers (Breuste 2003; Breuste et al. 2008; Gómez-Baggethun and Barton 2012). These ecosystem services provided in urban areas were addressed by major initiatives like the Millennium Ecosystem Assessment and the Economics of Ecosystems and Biodiversity (2011) and have received increasing attention as part of the policy debate on green infrastructure (European Environmental Agency 2011; DG Environment 2012). In particular, public parks play an important role in supporting biodiversity and providing important ecosystem services in urban areas (Bolund and Hunhammar 1999; Crane and Kinzig 2005; Gaston et al. 2005; Smith et al. 2005). In addition,

\section{实}

(c) 2015 Breuste and Rahimi; licensee. This is an Open Access article distributed under the terms of the Creative Commons Attribution License (http://creativecommons.org/licenses/by/4.0), which permits unrestricted use, distribution, and reproduction in any medium, provided the original work is properly credited. 
urban parks are often the only alternative green spaces, especially to those covered by trees, that were lost as a consequence of urbanization (Pauleit et al. 2005), and they play important roles in providing regulation, provisioning and cultural ecosystem services, such as air and water purification, wind and noise filtering (Chiesura 2004), preventing soil erosion (Binford and Buchenau 1993), accommodation of social interactions (Peters et al. 2010; Iamtrakul et al. 2005; Cranz 1983), providing hygiene and aesthetics (Ignatieva et al. 2011), reducing work-related stress (Kaplan and Kaplan 1989; Gobster and Westphal 2004), leisure, sport and recreational activities (Salazar and Menéndez 2007), biodiversity, urban cooling (Cao et al. 2010; Imai and Nakashizuka 2010; Kordowski and Kuttler 2010), selling price of nearby houses (Benson et al. 1998; Tyrväinen 1997), and increasing property values (Geoghegan et al. 1997; Tyrväinen 1997; Morancho 2003).

Access to nearby parks and natural settings is associated with improved mental health (Sugiyama et al. 2008; Payne et al. 2005), positive effects and reduced anxiety (More and Payne 1978), physical health (Payne et al. 2005), and healthy weight among children (Potwarka et al. 2008). Moreover, park users are more likely to achieve recommended levels of physical activity compared with non-users (Giles-Corti et al. 2005; Deshpande et al. 2005). There is also evidence that distance from parks and open space is inversely associated with use and physical activity behavior (Kaczynski and Henderson 2007), which might suggest that creating more neighborhood parks within walking distance to more residents could encourage physical activity participation in the population. Distance is often mentioned as the main environmental factor influencing the use of a green space (e.g., Coles and Bussey 2000; Van Herzele and Wiedemann 2003; Giles-Corti et al. 2005), and a distance of 300 to $400 \mathrm{~m}$ is seen as a typical threshold value after which the use frequency starts to decline (Grahn and Stigsdotter 2003; Nielsen and Hansen 2007). Other environmental factors such as the size of the green space, presence of facilities, and availability for activities are also thought to have an influence on the use of an urban green space (Van Herzele and Wiedemann 2003; Bedimo-Rung et al. 2005; Giles-Corti et al. 2005).

Accessibility is not easy to quantify, and there is no single best approach for measuring it (Gutiérrez 2001). Accessibility refers to an individual's ability to take part in a particular activity or set of activities (Lau and Chiu 2003). The choice of indicator affects the spatial pattern of accessibility (Talen and Anselin 1998). Some researchers have examined patterns of accessibility to certain services and the geographic relationship between service deprivation and area deprivation (Lindsey et al. 2001; Tsou et al. 2005).

There are relatively few studies that map the distance people have to travel to their nearest green space
(Barbosa et al. 2007; Comber et al. 2008; Kessel et al. 2009; Oh and Jeong 2007; Van Herzele and Wiedemann 2003). The results of these studies, all based on data from one or more cities, show that the majority of the population in these cities does not have access to a green space within $300 \mathrm{~m}$ of their homes; however, at least $90 \%$ of the population does have access to a green space within a 900- to 1,000-m radius. The European Environment Agency (EEA) reports similar findings for access to a green space within a 15-min walk in their 1995 assessment of a range of European cities (Stanners and Bourdeau 1995). The city of Copenhagen, Denmark, has recently adopted a new planning strategy that includes the aim of providing a green space within a $400-\mathrm{m}$ radius for at least $90 \%$ of its population by 2015 (Public Health Office Copenhagen 2006).

The Accessible Natural Green space Standards (ANGSt) in England model specifies guidelines for green space access provision:

- No person should live more than $300 \mathrm{~m}$ from their nearest area of a natural green space of at least 2 ha in size;

- There should be at least one accessible 20-ha site within $2 \mathrm{~km}$ from home;

- There should be one accessible 100-ha site within $5 \mathrm{~km}$;

- There should be one accessible 500-ha site within $10 \mathrm{~km}$ (Comber et al. 2008).

The reasons for higher demand for urban public parks in Near East and Middle East cities are cultural demands, higher urban population density, and lack of private open spaces for the majority of the urban residents. Urban parks in Iranian cities play an important role in providing ecological services, and access to them improve mental health and social communication. The public use and requirements of parks may also become different with the planners' viewpoints (Hayward and Wehitzer 1984). Public spaces in Iran can be considered multipurpose areas (Hami 2009). Urban parks are defined as public green spaces which provide opportunities for camping, recreation, and family gathering (Majnonian 1996). Parks in Iran are regarded as an important venue to fulfill residents' leisure times, and they are known as important destinations for residents in big cities such as Tabriz to spend even their holidays (Nohorly 1999). During the summer season in Iran, schools and universities are closed and also, due to rising temperature, park usage in Iran especially in Tabriz city based on Hami's (2009) research is during summer.

Several studies have examined the relationship between distance to green spaces and participation in physical activity. Giles-Corti et al. (2005) found that proximity to public open space was associated with higher levels of walking amongst residents in Perth, Australia. Hillsdon 
et al. (2006) found no relationship between distance to green spaces and self-reported leisure time physical activity amongst a cohort of adults in a British city. Studies that have measured the availability of a green space within the neighborhoods of participants have drawn similarly equivocal conclusions; in the Netherlands, Maas et al. (2008) found no association between a green space area and physical activity levels of adults. Conflicting findings have also emerged from studies that have examined the correlation between green space availability and bodyweight. For example, Potwarka et al. (2008) found no relationship between proximity to parks and overweight tendencies of Canadian children, while Nielsen and Hansen (2007) identified a significant association for Danish adults. These conflicting findings might reflect the diverse and complex influences on bodyweight, which include dietary behaviors as well as physical activity.

This paper aims to investigate the accessibility of parks in relation to social status of the inhabitants. This was investigated using the example of a clearly socially stratified city (Tabriz, Iran), which part of the urban society (by total number and social status) has better or worse access to urban parks.

\section{Methods}

\section{Description of the study area (Tabriz)}

The study was carried out in the city of Tabriz in the northwest area of Iran (Figure 1).
The city is increasingly faced with development and population growth. In the past half-century, industrial centers have developed on the periphery of Tabriz. The development of industry and its need for workers caused a great immigration from villages and small cities. With the increasing population in recent decades, Tabriz has also experienced extreme growth (Panahi 2000). In the last century, Tabriz was surrounded by gardens, had good climate, and was valued by most of the Iranian kings. In different points in history, Tabriz was chosen to be the capital of Iran. The recent expansion of Tabriz destroyed these gardens and has already affected the climate of the city.

Tabriz has been selected as a case study because it develops very rapidly which causes increasing demand for ecosystem services like recreation and is clearly structured by social status. It is easy to identify different categories of urban parks - Tabriz is located in overall semi-desert surroundings without recreational attractiveness for urban dwellers who are therefore limited to the ecosystem services of the urban parks.

\section{Data collection instrument}

Data were collected for Tabriz parks analyzing from Tabriz Parks and Green Spaces Organization (TPGSO) and completed on-site survey. For analyzing of urban land use, land uses map are collected from Tabriz municipality, Urban Planning Organization in Tabriz, and Consultant engineering maps. The classification of social status (high,

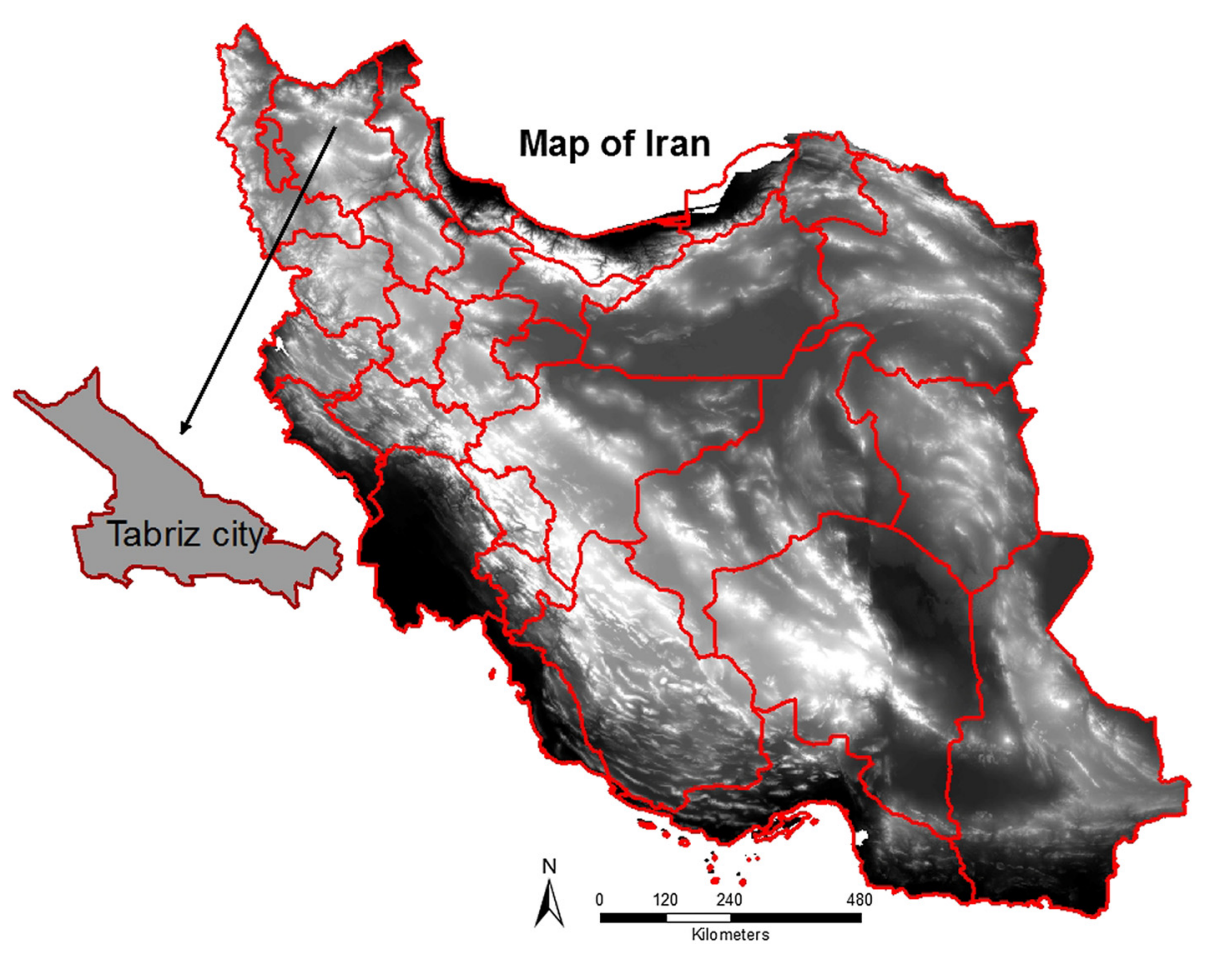

Figure 1 Tabriz city in Iran. 
middle, and low) was carried out by statistical blocks data. For the completion of all data, we used AutoCAD, ArcGIS, and excel software, and the final maps produced in shape file format for analyzing.

\section{Accessibility and categorization of urban parks}

The Iranian urban park types are as follows (Majnonian 1996; Ghorbani 2009) (see Table 1):

- Pocket parks: pocket parks are small spaces that serve community members within an immediate vicinity. Pocket parks generally average 0.5 ha or less in size. They are available where opportunities for neighborhood parks are unavailable but offer some of the same characteristics as neighborhood parks; however, they offer limited amenities due to their small size and accessibility radius is $200 \mathrm{~m}$.

- Neighborhood parks: neighborhood parks are in scale between pocket and community parks but provide similar amenities within walking distance of residential areas. Neighborhood parks are more than 0.5 and lesser than 2 ha in size and the accessibility radius is $600 \mathrm{~m}$.

- Community parks: each community park should be available to the entire community. The parks should be easily accessible by all residents and accessibility radius is $1,200 \mathrm{~m}$. Typically, community parks are 2 to 4 ha in size.

- Regional parks: regional parks are generally much bigger than a community park in size, and its accessibility radius is $2,500 \mathrm{~m}$.

- City parks: city parks are established for all urban dwellers and are more than 10 ha in size with several recreation facilities. The accessibility is a $30-$ min drive or more.

\section{Social structure of Tabriz}

Spatial expansion of Tabriz has caused spatial changes in social structure. Migration from small towns and villages surrounding the city of Tabriz in East Azerbaijan province comprised mainly of workers and unskilled people. This migration process has led to a growth of informal settlements in Tabriz and caused tremendous changes in social structure (Asgharizamani 2000, and social polarization in the neighborhoods (Panahi 2000) (Table 2).

To identify socially segregated areas according to socioeconomic groups, we used the results of studies by Adimark (2004) and Romero et al. (2012) and census data (Iranian Statistical organization 2005) and municipal plans (Municipality of Tabriz 2012). The data used for the social classification are education, occupation, household dimension, income (Iran statistical center 2005), land value (land price map, Babaiaghdam 2007), building type and property sizes (GIS-based map, Municipality of Tabriz 2012, and informal settlement map (Zista Consulting Engineers 2005). Using these data, the socio-economic groups have been broken down into three categories: high, middle, and low. Figure 2 shows the classification of social status (high, middle, and low) and indicates that the west, northwest, and southwest areas of Tabriz are occupied by the lower social groups, and the east, northeast, and southeast by middle and part of southeast, and northeast areas of Tabriz are occupied by inhabitants of high social status.

\section{Definition of potential user areas}

Distance is often mentioned as the main environmental factor influencing the use of a green space (e.g., Coles and Bussey 2000; Van Herzele and Wiedemann 2003; Giles-Corti et al. 2005), and a distance of 300 to $400 \mathrm{~m}$ is seen as a typical threshold value after which the use

Table 1 Urban park area and accessibility in Iran and Tabriz

\begin{tabular}{|c|c|c|c|c|}
\hline Parks & Description & Area (ha) & Access & $\begin{array}{l}\text { Number of } \\
\text { parks in Tabriz }\end{array}$ \\
\hline Pocket park & $\begin{array}{l}\text { A mini park or vest-pocket parks are an urban open space at the } \\
\text { very small scale. Pocket parks scattered throughout the urban } \\
\text { areas where they serve the immediately local population. }\end{array}$ & 0.5 & $200 \mathrm{~m}$ & 47 \\
\hline Neighborhood park & $\begin{array}{l}\text { A neighborhood park is typically a small park, usually between } 0.5 \text { and } 2 \text { ha. } \\
\text { They typically have playground facilities and are located within a } 600-\mathrm{m} \\
\text { distance of residential areas. Parents with young children are the main users. }\end{array}$ & 0.5 to 2 & 200 to $600 \mathrm{~m}$ & 53 \\
\hline Community park & $\begin{array}{l}\text { Community parks serve more than one neighborhood but are not } \\
\text { intended to serve the city as a whole. Community parks have more } \\
\text { intensive recreational facilities such as sports fields and recreational facilities. }\end{array}$ & 2 to 4 & 600 to $1,200 \mathrm{~m}$ & 16 \\
\hline Regional park & $\begin{array}{l}\text { A regional park is a mid-sized park providing a range of facilities and activity } \\
\text { space for recreation or sport. These parks cater for large groups and are } \\
\text { appealing to a range of users or groups. They serve several communities } \\
\text { or suburbs and are a fairly well-known destination for those people living within } \\
\text { their catchment. In fact, these parks are the major parks in urban regions. }\end{array}$ & 4 to 10 & 1,200 to $2,500 \mathrm{~m}$ & 11 \\
\hline City park & $\begin{array}{l}\text { A city park is a major recreation or sports park that offers a wide variety of } \\
\text { opportunities to a broad cross section of residents of a planning scheme } \\
\text { area. These parks are large in size and well known amongst residents; } \\
\text { these parks are major destinations within a planning scheme area. }\end{array}$ & $\begin{array}{l}\text { More } \\
\text { than } 10\end{array}$ & 30-min drive & 6 \\
\hline
\end{tabular}


Table 2 Social structure problems in Tabriz

\begin{tabular}{|c|c|c|}
\hline Problems & Causes & Consequences \\
\hline \multirow[t]{2}{*}{$\begin{array}{l}\text { Uncontrolled migration } \\
\text { of population to Tabriz }\end{array}$} & $\begin{array}{l}\text { - Concentrating facilities and activities } \\
\text { in the Tabriz urban area }\end{array}$ & \multirow[t]{2}{*}{ - Evacuation of rural areas } \\
\hline & - Industrial development from 1955 & \\
\hline \multirow[t]{3}{*}{$\begin{array}{l}\text { High percentage of rural } \\
\text { migrants with lack of expertise }\end{array}$} & \multirow[t]{3}{*}{$\begin{array}{l}\text { - Lack of employment opportunities } \\
\text { and services in rural areas }\end{array}$} & $\begin{array}{l}\text { - Establishment of an informal } \\
\text { sector in the urban economy }\end{array}$ \\
\hline & & $\begin{array}{l}\text { - Employment of migrants in } \\
\text { an informal sector }\end{array}$ \\
\hline & & $\begin{array}{l}\text { - Formation of marginalized } \\
\text { and low-income neighborhoods }\end{array}$ \\
\hline $\begin{array}{l}\text { High sex ratio, especially } \\
\text { in the older age group }\end{array}$ & - Permanent migration of unmarried young men & $\begin{array}{l}\text { - Population imbalance between } \\
\text { males and females }\end{array}$ \\
\hline \multirow[t]{2}{*}{ Young people } & - High rates of fertility & \multirow{2}{*}{$\begin{array}{l}\text { - Lack of facilities and services } \\
\text { to active group }\end{array}$} \\
\hline & - High proportion of young migrants in Tabriz & \\
\hline \multirow[t]{3}{*}{$\begin{array}{l}\text { Social stratification in neighborhood } \\
\text { areas especially in recent years }\end{array}$} & $\begin{array}{l}\text { - Unequal distribution of income } \\
\text { between social groups. }\end{array}$ & \multirow{3}{*}{$\begin{array}{l}\text { - Significant differences in neighborhoods } \\
\text { based on the level of services and quality } \\
\text { of facilities, residential units, and street network }\end{array}$} \\
\hline & $\begin{array}{l}\text { - Employment of unskilled rural } \\
\text { migrants in the informal economy }\end{array}$ & \\
\hline & $\begin{array}{l}\text { - Assessment and appraisal of land and housing } \\
\text { using land quality and neighborhoods facilities }\end{array}$ & \\
\hline
\end{tabular}

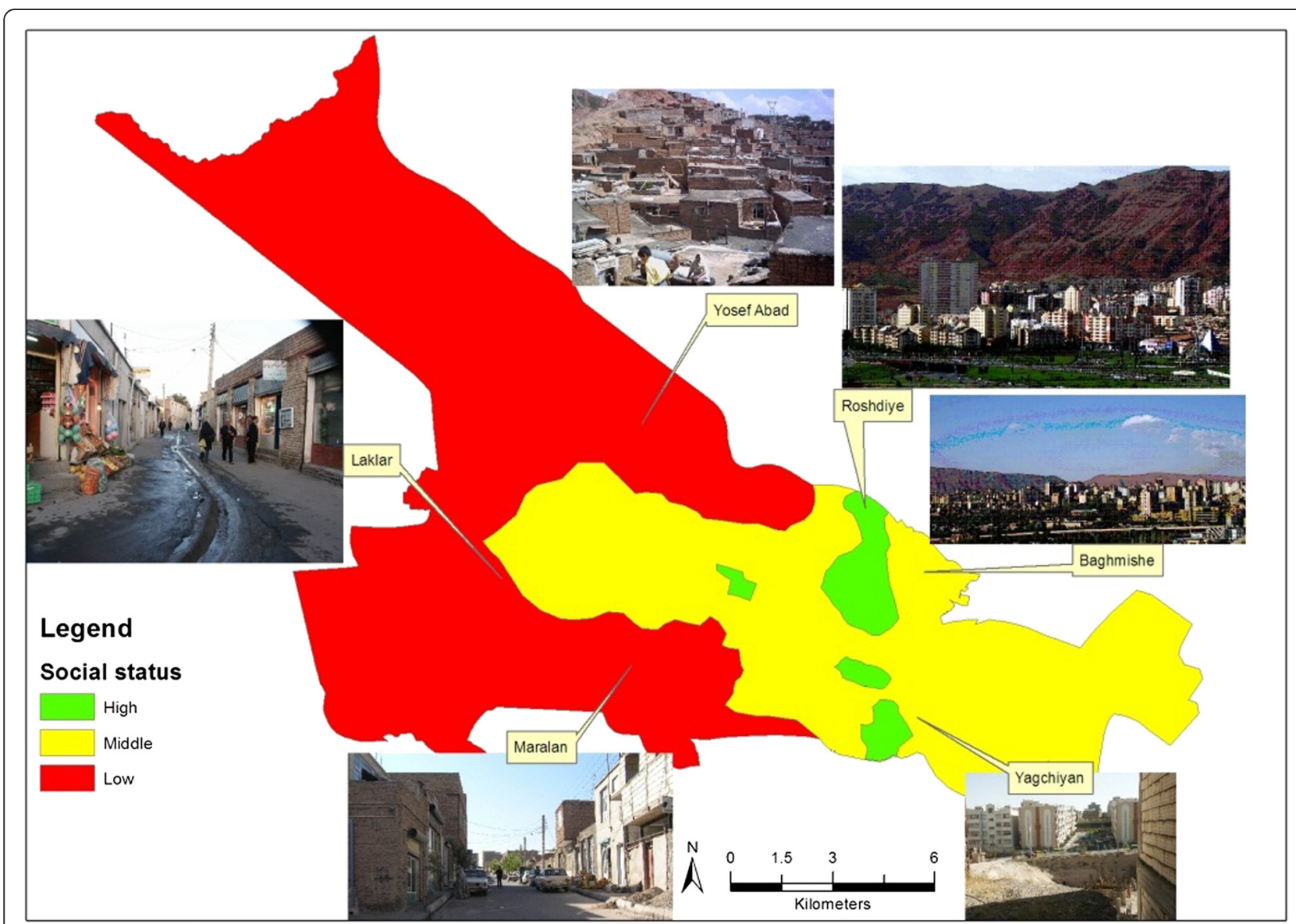

Figure 2 Classification of social status (author's illustration). 
frequency starts to decline (Grahn and Stigsdotter 2003; Nielsen and Hansen 2007). Other environmental factors such as size of the green space, presence of facilities, and possibility for activities are also mentioned to have an influence on the use of an urban green space (Van Herzele and Wiedemann 2003; Bedimo-Rung et al. 2005; Giles-Corti et al. 2005).

Table 3 is based on the minimum target in which each urban resident should be able to enter at least one green space on each functional level of the indicated maximum distance and minimum surface based on a research by Van Herzele and Wiedemann (2003).

\section{Data analysis}

In this paper, the parks' accessibility with social group factor is analyzed using the buffer method. The potential user areas were defined differently depending on type of park following the results of Ghorbani (2009):

- Pocket parks: 2 rings, $100 \mathrm{~m}$, and second $200 \mathrm{~m}$;

- Neighborhood parks: 3 rings, 200, 400, and 600 m;

- Community parks: 3 rings, 300, 600, and 1,200 m;

- Regional parks: 3 rings, 1,200, 2,000, and 2,500 m;

- City parks: 3 rings, 1,000, 2,000, and 3,000 m.

All data on parks and land use maps were compiled using a GIS system (ArcGIS 10). All 132 parks in Tabriz were investigated.

\section{Results}

Urban land use distribution and social groups' accessibility

For the evaluation of urban land use in this paper, land use categories of Tabriz are classified in six clusters. The result in Table 4 shows that $33.6 \%$ of the area of Tabriz is undeveloped land (semi-desert), followed by residential area at $22.8 \%$, but recreational area composes only $7.2 \%$ of urban area. Table 4 shows that $6 \%, 8.2 \%$, and $21.3 \%$ of land in low, middle, and high social status areas are covered by recreational land use. The development of recreational areas is also related to social segregation.

The distribution of land use shows, in the central area of Tabriz with mostly residential districts, fewer recreational

Table 3 Minimum standards for urban green spaces (MIRA-S 2000)

\begin{tabular}{lcc}
\hline Functional level & $\begin{array}{c}\text { Maximum distance } \\
\text { from home }(\mathbf{m})\end{array}$ & $\begin{array}{c}\text { Minimum } \\
\text { surface (ha) }\end{array}$ \\
\hline Residential green & 150 & - \\
Neighborhood green & 400 & 1 \\
Quarter green & 800 & 10 (park: 5 ha) \\
District green & 1,600 & 30 (park: 10 ha) \\
City green & 3,200 & 60 \\
\hline
\end{tabular}

areas. The most recreational areas are located in the east and northeast (Figure 3).

\section{Quantitative accessibility of different park categories (number of potential visitors)}

Because of no recreational alternatives in the surroundings of Tabriz (semi-desert), urban parks are potentially important places for recreation of the population of Tabriz. In total, the 132 parks consist of different park categories (Figures 4 and 5).

The analysis shows that the number and distribution of parks does not explain accessibility. The park space per capita in Tabriz is $2.6 \mathrm{~m}^{2}$ while the standard target, based on urban planning ministry proposals, is 7 to $12 \mathrm{~m}^{2}$ and was not met. The park distribution shows that several areas of the city have poor accessibility to parks (see Figure 3). Only 32.3\% of urban households in Tabriz have access to parks (all park categories included) $300 \mathrm{~m}$ from their homes to parks. This accessibility is clearly connected with social status. Table 5 illustrates that $84 \%$ of high social status population have urban parks within $300 \mathrm{~m}$, but the accessibility for low and middle social status groups is only $27 \%$ and $29 \%$, respectively.

This differs for different park categories but always demonstrates the same connection of social status and park accessibility (see Figures 6, 7, 8, 9 and 10; Tables 6).

\section{Accessibility of different park categories by social groups} Valuation of a social group's accessibility to pocket parks for all socio-economic groups was unsuitable, and approximately $90 \%$ of dwellers in Tabriz do not have access to pocket parks. The equipment with neighborhood parks for low social status groups do not have good accessibility for most of the neighborhood parks, which are mostly located in high and middle social status group areas. In community park assessment, low and middle social status groups have poor accessibility, but for regional parks, they had the best accessibility for all social status groups and the most of the social status group's profit. Therefore, regional parks are most accessible for mostly all social status levels compared to other park categories. City parks again show a difference in accessibility by social status groups. Only $51.8 \%$ of low social status groups have accessibility, meanwhile, $97 \%$ of high social status groups profit from city parks (Table 7 and Figure 11).

The results show that only the distribution of regional parks was suitable for all social status groups and the lowest accessibility to parks is to pocket parks. The distribution of parks in other types, however, was based on social segregation. As the results indicate, the best access to parks was for high social status groups and the worst access was for low social status groups.

Most parks are best accessible for high social status groups, and low social groups suffer by reduced access. 
Table 4 Land use distribution and social status access

\begin{tabular}{|c|c|c|c|c|c|c|c|c|}
\hline \multirow[t]{3}{*}{ Land use } & \multirow[t]{3}{*}{ Characteristics } & \multirow[t]{3}{*}{ Area (ha) } & \multicolumn{6}{|c|}{ Social status } \\
\hline & & & \multicolumn{2}{|l|}{ Low } & \multicolumn{2}{|l|}{ Middle } & \multicolumn{2}{|l|}{ High } \\
\hline & & & Area (ha) & Percent & Area (ha) & Percent & Area (ha) & Percent \\
\hline Agricultural & - & $3,460.6$ & $3,203.03$ & 20.88 & 329.77 & 3.87 & 0.8 & 0.1 \\
\hline Industrial & - & $1,107.835$ & 847.48 & 5.52 & 260.83 & 3.06 & 2.1 & 0.2 \\
\hline Not used land & - & $7,914.799$ & $4,453.63$ & 29.03 & $3,935.51$ & 46.17 & 333.2 & 35.9 \\
\hline Recreation & Green spaces, gardens, and tourism area & $1,687.268$ & 918.11 & 5.98 & 698.43 & 8.19 & 197.6 & 21.3 \\
\hline Residential & - & $5,365.516$ & $2,791.99$ & 18.20 & $2,323.52$ & 27.26 & 323.2 & 34.9 \\
\hline Service & $\begin{array}{l}\text { Education, clinics and hospitals, commercial and } \\
\text { business centers, offices, cultural, religious, infrastructure } \\
\text { facilities, airports, terminals, military, and parking }\end{array}$ & $4,046.758$ & $3,126.51$ & 20.38 & 975.75 & 11.45 & 70.5 & 7.6 \\
\hline Sum & - & $23,582.78$ & $15,340.74$ & 100.00 & $8,523.81$ & 100.00 & 927.49 & 100.00 \\
\hline
\end{tabular}

Urban park areas per capita for social groups (low, middle, and high) are $1.3 \mathrm{~m}^{2}$ for low, $2.1 \mathrm{~m}^{2}$ for middle, and $6.1 \mathrm{~m}^{2}$ for high (average $5.6 \mathrm{~m}^{2}$ ).

\section{Discussion}

\section{Why are urban parks so important?}

Today, the number of built-up areas is growing to population rate and has increased in most Iranian cities by fast urbanization and industrialization over recent years. Urban parks have a strategic importance for the quality of life in Iranian urban society and play a significant role in increasing the livability of cities (Biddulph 1999).
Urban green spaces and their social function and usage Urban green spaces and recreational land uses are perceived to have effects on social cohesion, as all groups of people are related to nature regardless of their social status (Schetke et al. 2010). Contact with nature influences people's health (Gidlof-Gunnarsson and Ohrstrom 2007; Qureshi et al. 2010) and has psychological benefits by reducing stress (Ulrich 1984; Ulrich et al. 1991), restoring attention (Kaplan and Kaplan 1989), reducing criminal and antisocial behavior (Kuo and Sullivan 2001), and positively affecting self-regulation and restorative experiences (Korpela et al. 2001; Hartig et al. 2003; Korpela and Yle'n 2007; van den Berg et al. 2007). In addition to the

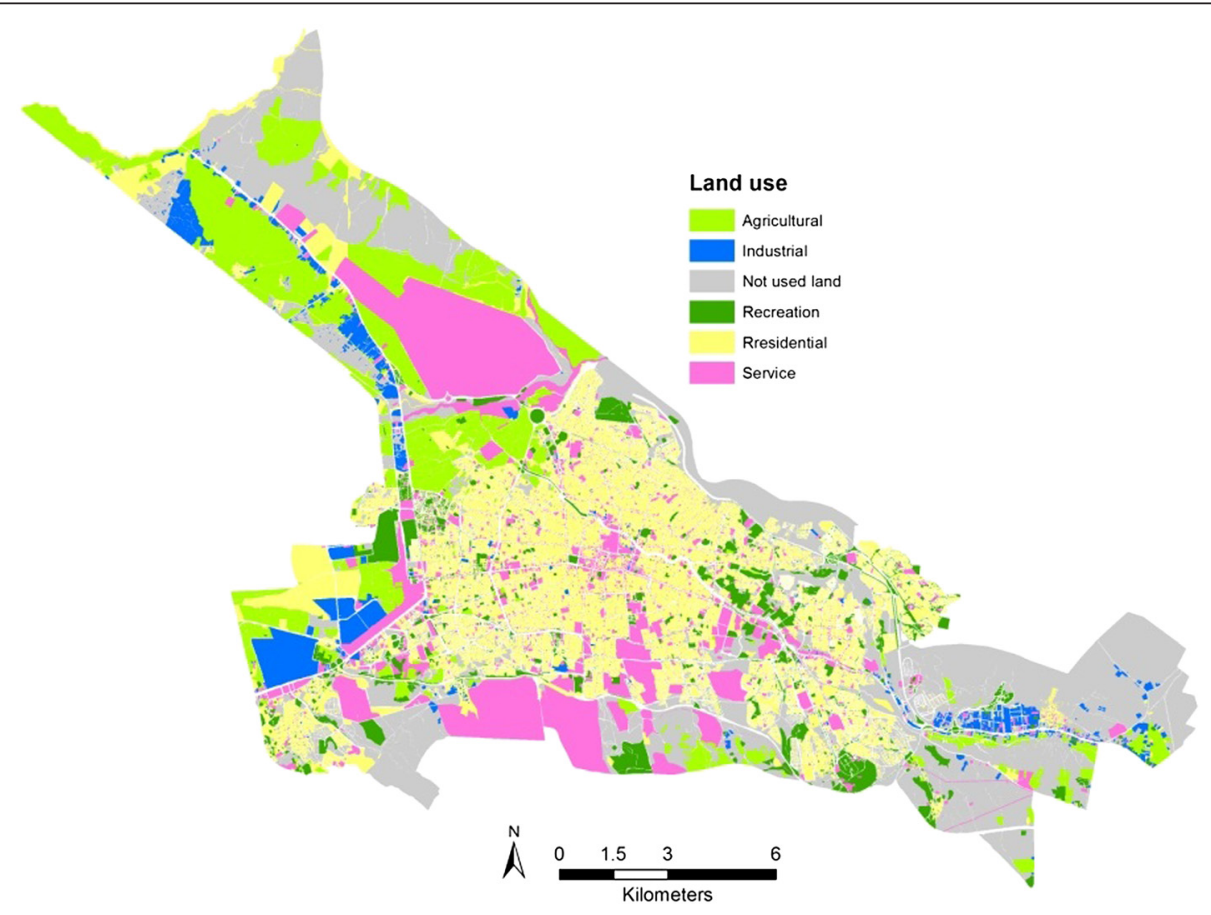

Figure 3 Land use distribution in Tabriz (author's illustration). 


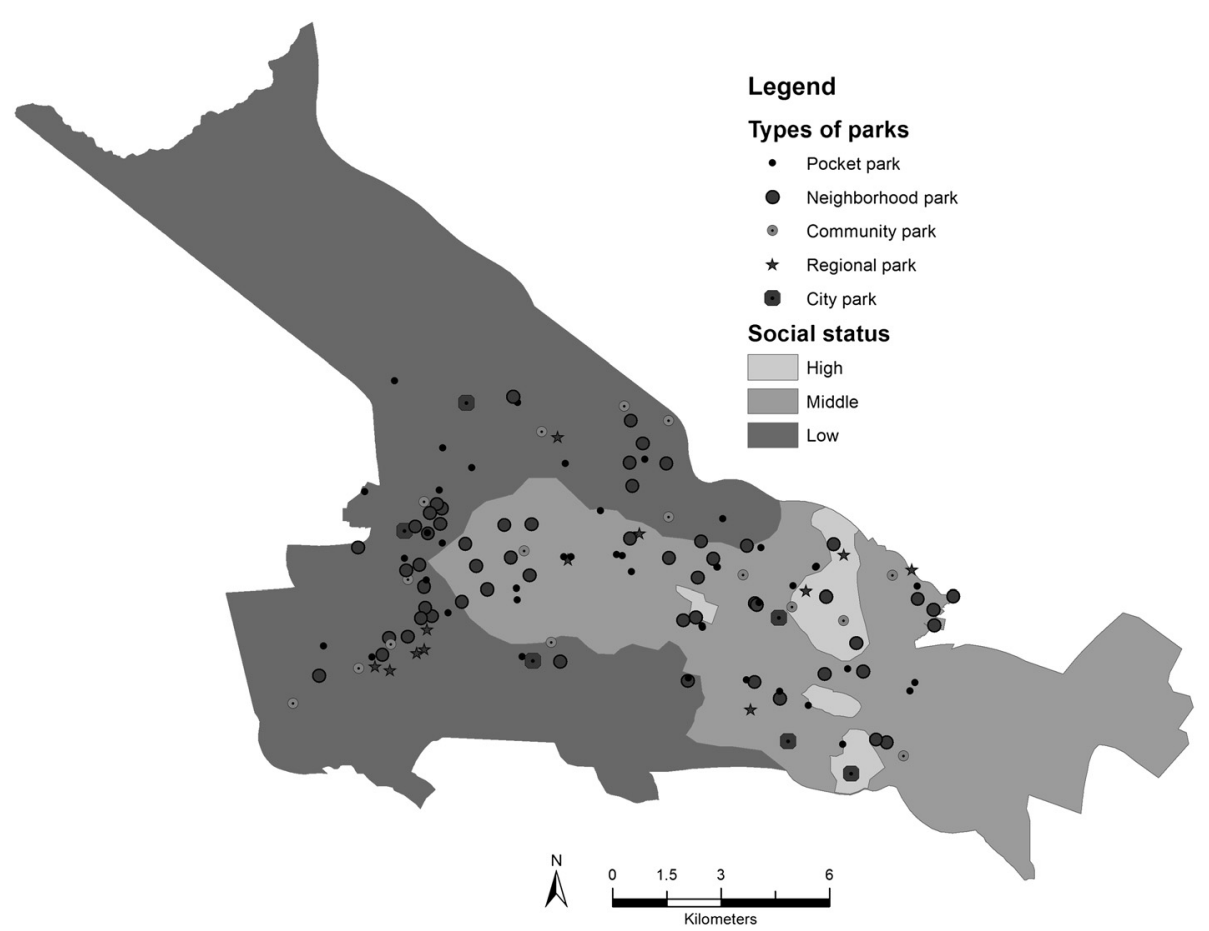

Figure 4 Distribution of all types of park in Tabriz (author's illustration).

psychological benefits from contact with nature, there are also direct physical health benefits, such as addressing issues associated with obesity, increased longevity, and self-reported health (Pretty et al. 2006).

According to Khosravaninezhad et al.'s (2011) research on urban parks in Tehran, the result is that all people, at all times and in all age groups, notice and appreciate the role of nature and the benefits of it for their improved mental, psychological, and social well-being. Most people feel joyous and happy when they are close to nature, and they identify parks as a place to revitalize and refresh themselves. It shows that parks directly and indirectly raise the quality of life. Also, according to the survey of urban park visitors about the attraction and deterrent factors of urban parks, it was found that most people prefer to spend their spare time outside of their residences in the parks and enjoy being in other people's company. Results show that, firstly, people satisfy a part of their psychological and social needs in parks, and secondly, development and expansion of urban parks and green spaces falls in line with the development of Tehran, leading to an increase in the quality of urban life. Findings also include the need for upgrading park facilities considering that the citizens of Tehran spend 2 to $4 \mathrm{~h}$ a day for recreation and leisure in the large urban parks. At the same time, because of the importance of the accessibility factor for the usage of urban parks by the citizens of Tehran, creation and expansion of parks in neighborhoods could increase the availability of parks for the people and raise their quality of life (Khosravaninezhad et al. 2011).

Does planning of parks support social segregation, or does social segregation support development of public parks?

Residential segregation is a form of physical and functional separation of spaces inhabited by different social groups living in the city. As a consequence, segregation might imply different residential distributions with different densities of population, different types of houses, and also different public and private green spaces (Weiland et al. 2011; Romero et al. 2012). There is a concern that access to the countryside and urban green spaces by different ethnic and religious groups is limited. Green spaces provide important environmental facilities, and they are a highly valued point of contact with nature (Kahn 1999) and offer health benefits (Frumkin 2001).

Heynen et al. (2006) analyzed the spatial distribution of urban green spaces with income. They found a strong positive correlation between the amount of residential canopy cover and median household income and implied that any investment in green spaces that was not carefully targeted would benefit the wealthy rather than the socioeconomically deprived residential areas.

In Iranian cities, the biggest and best equipped parks are located in high social status group areas. Social segregation supports the building of public parks in Iranian cities and spatially in big cities (Tehran, Esfahan, Tabriz and Shiraz) 


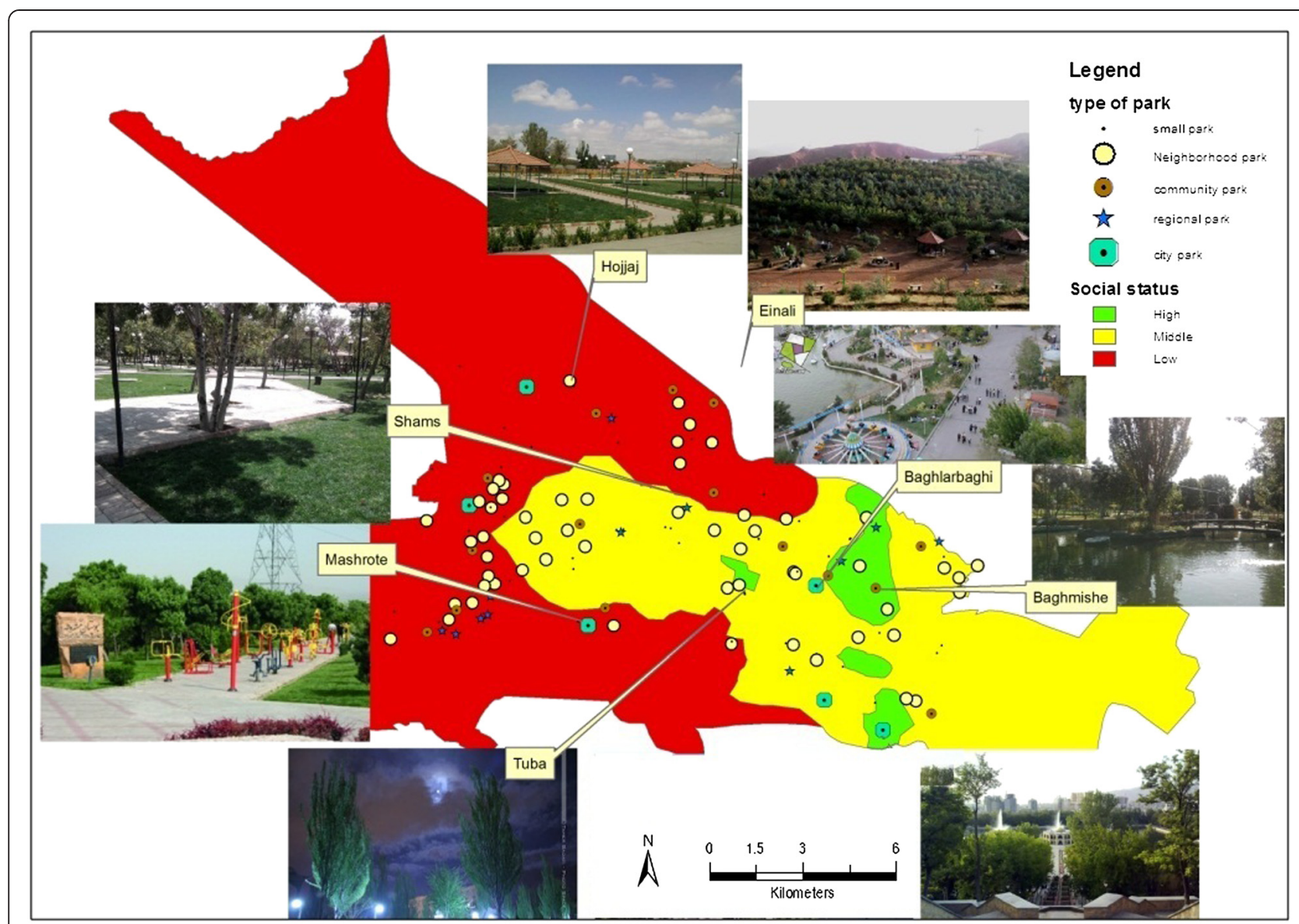

Figure 5 Distribution of all types parks facilities (author's illustration).

(Daneshpour and Mahmoodpour 2009; Khosravaninezhad et al. 2011; Hami et al. 2001).

\section{Do all people have access to the parks?}

Not all people in cities have access to parks and green spaces, and several studies have examined green space access in European cities. The Dutch government requires that sufficient opportunities exist for access to outdoor recreation, and a recent analysis of green space availability in the Netherlands found that $67 \%$ and $83 \%$ of neighborhoods had ready access to recreational opportunities for walking and cycling, respectively (De Vries and Van Zoest 2004). Depending on which definition of green space one

Table 5 Accessibility in $\mathbf{3 0 0} \mathrm{m}$

\begin{tabular}{llll}
\hline Social status & Population & $\begin{array}{l}\text { Population } \\
\text { in } \mathbf{3 0 0} \mathbf{~ m}\end{array}$ & $\begin{array}{l}\text { Percent of population } \\
\text { in } \mathbf{3 0 0} \mathbf{~ m}\end{array}$ \\
\hline Low & 732,455 & 197,763 & 27.0 \\
Middle & 555,929 & 161,219 & 29.0 \\
High & 109,676 & 92,127 & 84.0 \\
Sum & $1,398,060$ & 451,109 & 32.3 \\
\hline
\end{tabular}

uses, $64 \%$ or $72 \%$ of Sheffield's households in the UK fail to meet this target (Barbosa et al. 2007).

Therefore, as well as being concerned with the overall number of households having green space within a specified distance, policymakers need to consider the problems of these distributions and the very large distances of some households from any public green space. For example, the distance to the nearest municipal park from some households in Sheffield is more than 20 times the English Nature recommendation (Barbosa et al. 2007). Also, the distancebased measures of access could be refined to include travel constraints, such as physical and psychological barriers to pedestrian movement (Brown et al. 2007).

\section{Social status and accessibility of parks in Iran}

In Iranian cities, the social status of users of urban parks has been important in their perception. It has been deduced that the use of public parks has become a major source of leisure and recreational activity for lower income groups and a major refuge for lower income groups from the burden of their routine life in Iranian cities. As there is an evident socio-spatial dichotomy in Tehran, the capital of Iran, the non-local lower income 


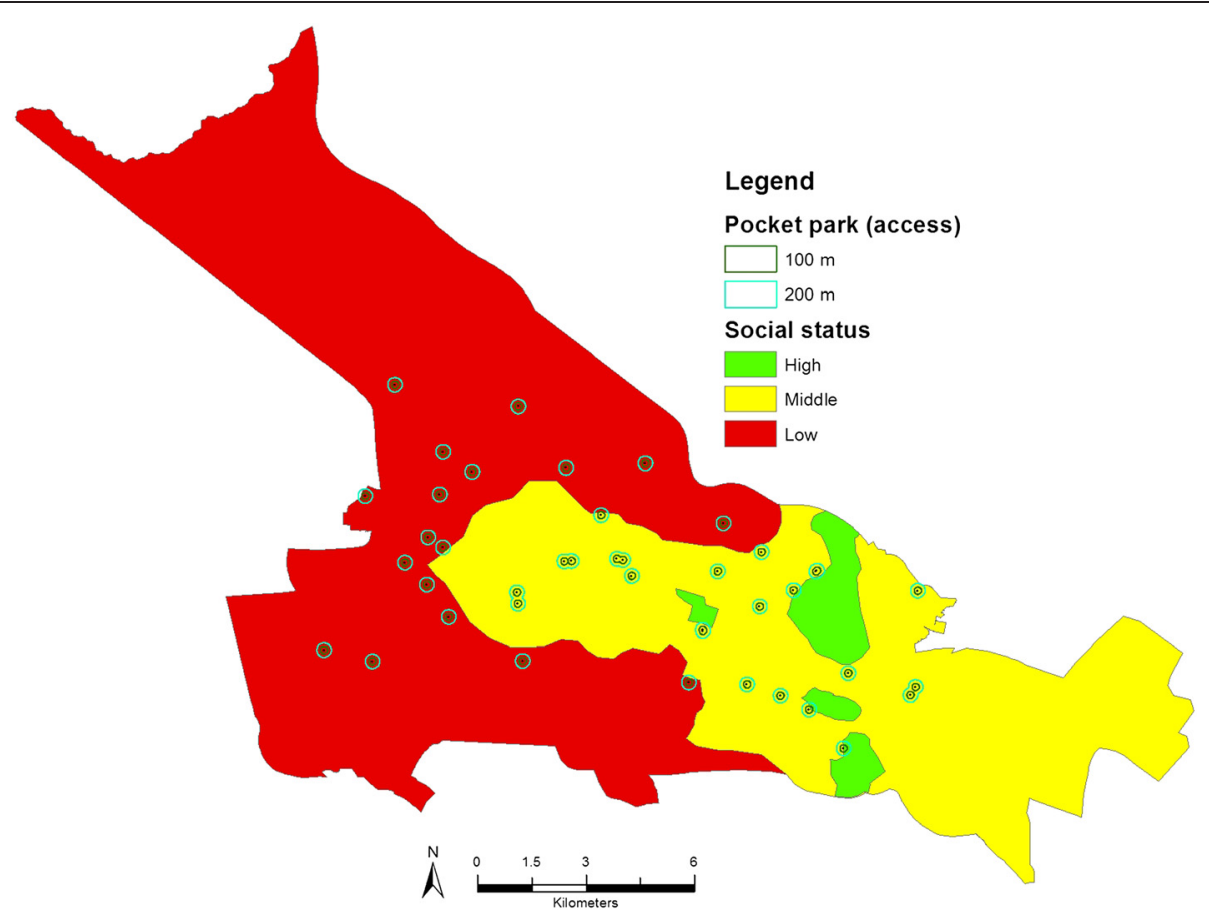

Figure 6 Distribution of pocket park and buffer accessibility (author's illustration).

groups living in dense residential areas of the southern parts of Tehran use the urban parks in the northern parts of the city. This has become one of the major barriers of using these parks - especially during the weekends and public holidays - by the more well-off residents of the northern parts of the city. Another major factor of low usage of public parks in Tehran - as was deduced from the survey - is the physically inactive lifestyle of many of the better-off and educated sections of this city's residents. This has become a major barrier

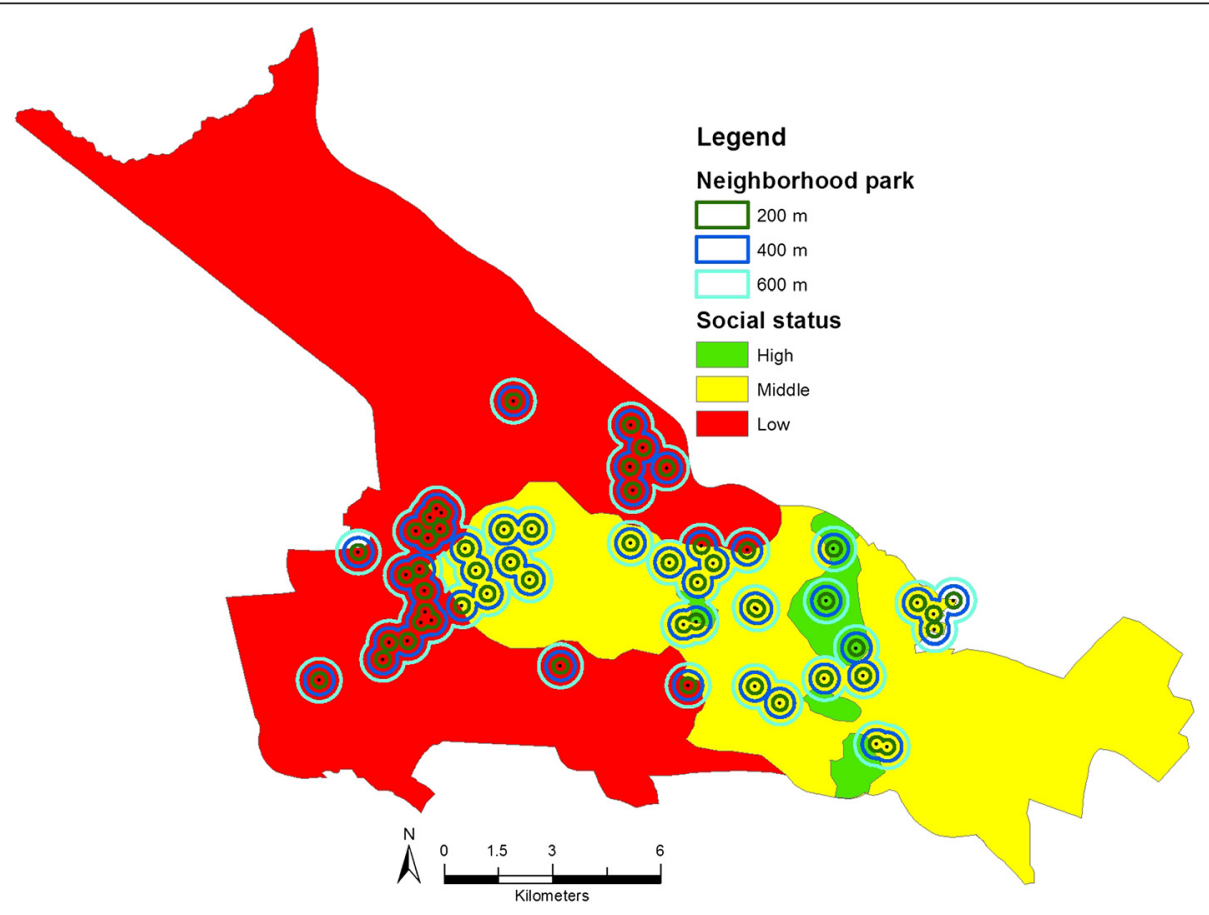

Figure 7 Distribution of neighborhood parks and buffer accessibility (author's illustration). 


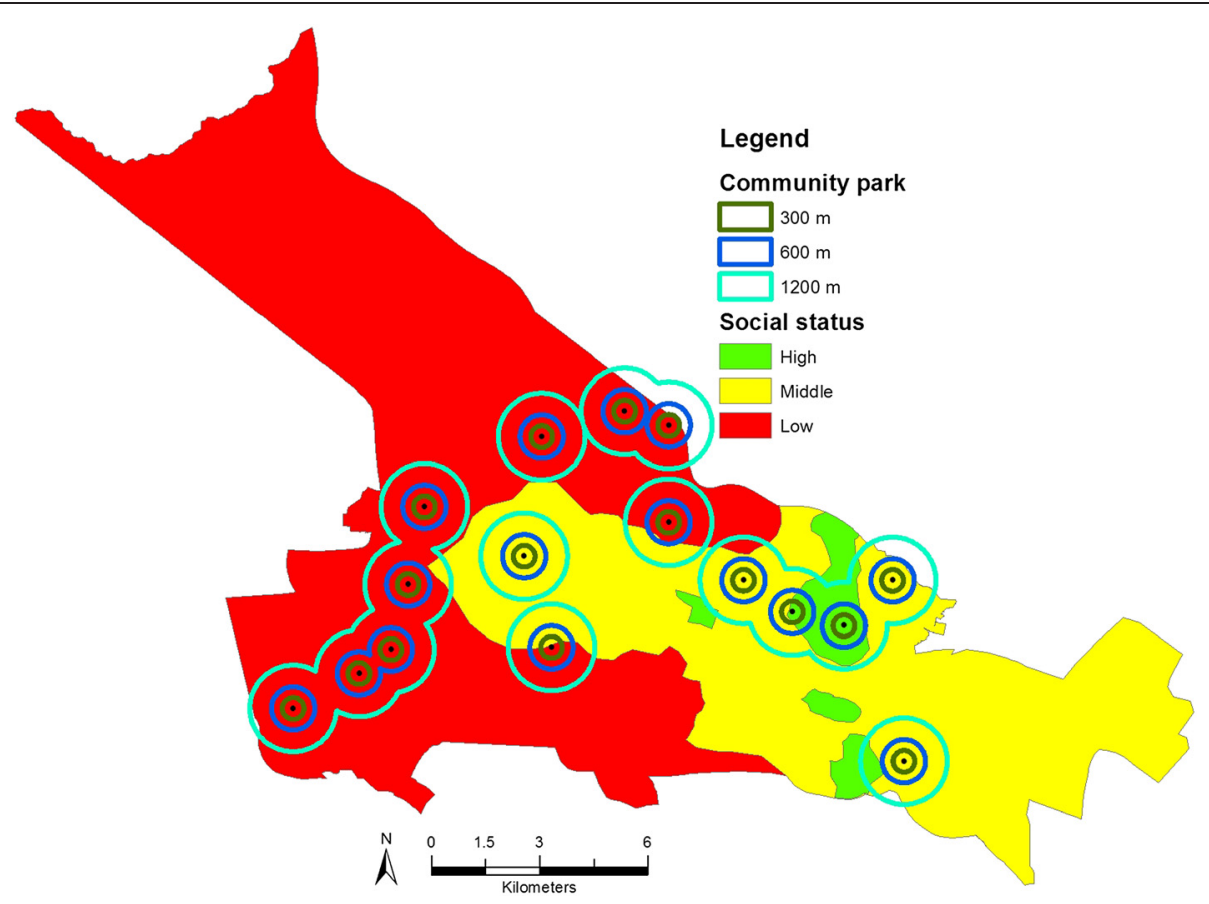

Figure 8 Distribution of community parks and buffer accessibility (author's illustration).

of increasing their use of public parks as opposed to their personal or gated private open spaces, whether in Tehran, in the holiday resorts surrounding Tehran, or in the coastal areas to the north of the country (Daneshpour and Mahmoodpour 2009).
The situation in Tehran seems to be contrary to the situation in some countries in which there is an increasing shift towards privatization of urban parks. The use of urban public parks has been enhanced especially for the lower income groups, which do not own or have

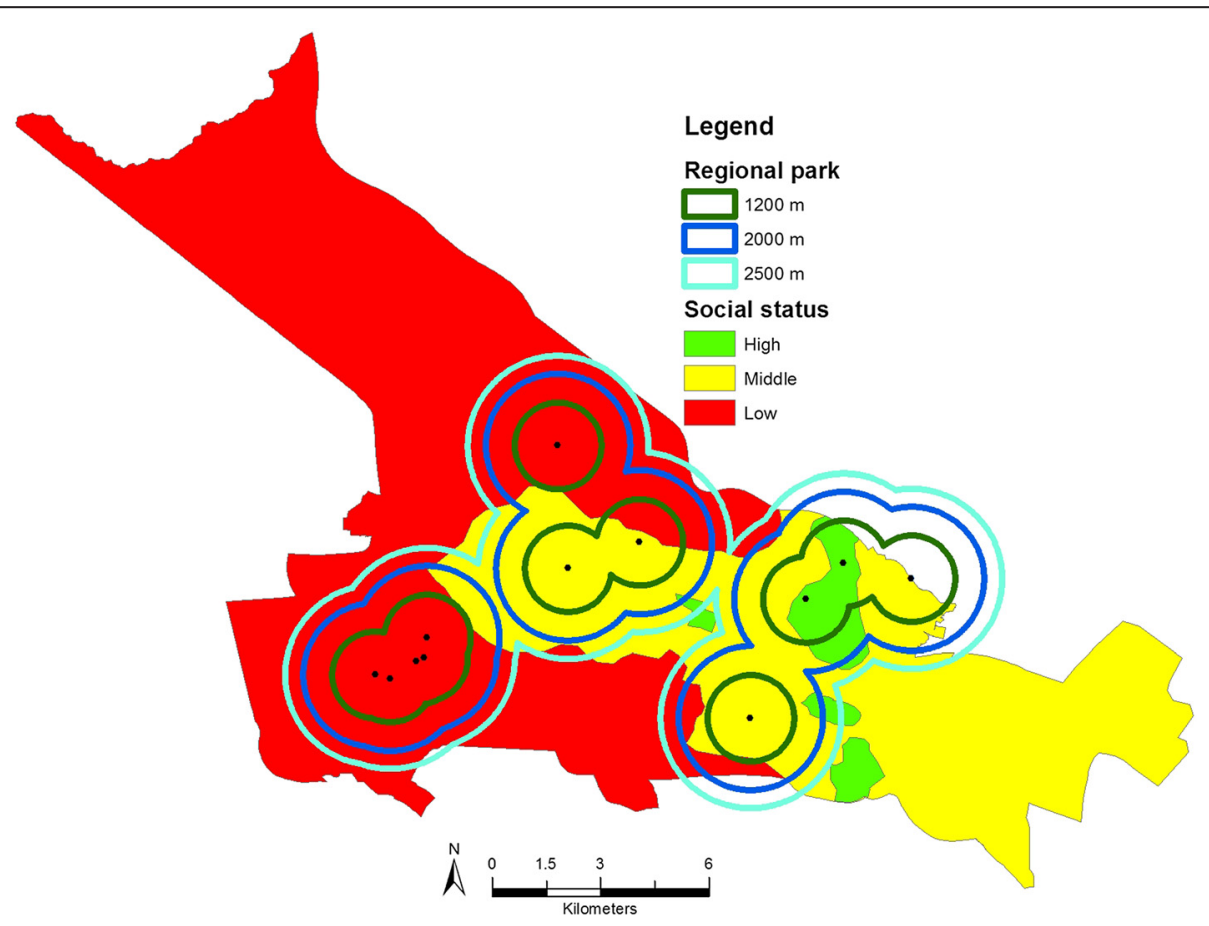

Figure 9 Distribution of regional parks and buffer accessibility (author's illustration). 


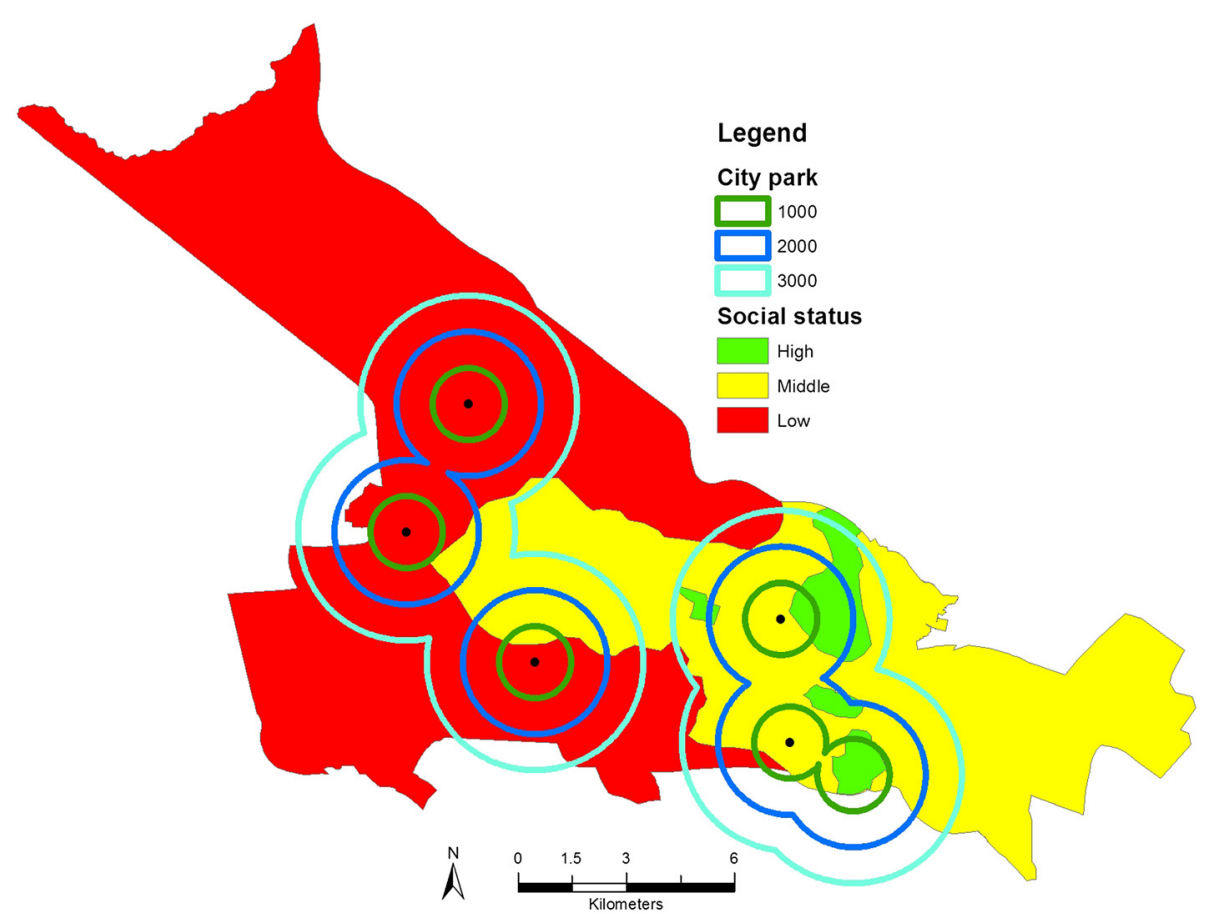

Figure 10 Distribution of city parks and buffer accessibility (author's illustration).

access to property suitable for spending their leisure time (Daneshpour and Mahmoodpour 2009).

Developing a green space strategy is a good opportunity for improving the quality of life in the Iranian cities, and appropriate accessibility to green space is one basic strategy in a master plan (Rahimi 2013). The parks and green space department in large cities in Iran supplies green space and park strategies and propose the accessibility of type of parks (pocket, neighborhood, community, regional, and city parks) as well as their amenities and outdoor furnishings. Also, in the master and detail plans in Iranian cities, distribution of green spaces, strategies for the development of parks, management, and planning is too less based on people's demand (Saidnia 2004).

Many studies have examined access to green spaces and participation in physical activities. But a little research has been done about accessibility and social status. In this work, accesses to all kinds of parks are investigated by different social groups and poor areas to access are specified, and social segregation for park accessibility in this research is analyzed. In the others works, percent of accessibility (De Vries and

Table 6 Accessibility in buffer rings

\begin{tabular}{|c|c|c|c|c|c|c|}
\hline \multirow[t]{2}{*}{ Type of park } & \multirow{2}{*}{$\begin{array}{l}\text { Name } \\
\text { of parks }\end{array}$} & \multicolumn{3}{|c|}{ Number of population in buffer ring } & \multirow{2}{*}{$\begin{array}{l}\text { Sum population } \\
\text { in three rings }\end{array}$} & \multirow{2}{*}{$\begin{array}{l}\text { Percent of } \\
\text { population for park } \\
\text { access in Tabriz }\end{array}$} \\
\hline & & First ring & Second ring & Third ring & & \\
\hline \multirow[t]{7}{*}{ City parks } & Elgoli & 12,055 & 31,812 & 13,577 & 57,444 & 4.1 \\
\hline & Saeb & 25,342 & 39,602 & 22,886 & 87,830 & 6.3 \\
\hline & Baglarbaghi & 2,022 & 72,566 & 100,560 & 175,148 & 12.5 \\
\hline & Big park & 9,563 & 20,926 & 66,708 & 97,197 & 7.0 \\
\hline & Sanat & 23,925 & 80,059 & 104,337 & 208,321 & 14.9 \\
\hline & Mashrote & 43,153 & 126,521 & 109,858 & 279,532 & 20.0 \\
\hline & Sum & 116,060 & 371,486 & 417,926 & 905,472 & 64.8 \\
\hline Regional parks & Sum & 403,078 & 548,832 & 321,725 & $1,273,635$ & 91.1 \\
\hline Community parks & Sum & 80,243 & 233,382 & 549,735 & 863,360 & 61.8 \\
\hline Neighborhood parks & Sum & 180,953 & 384,676 & 422,874 & 988,503 & 70.7 \\
\hline Pocket parks & Sum & 47,728 & 100,786 & 0 & 148,514 & 10.6 \\
\hline
\end{tabular}


Table 7 Type of parks and social status profits

\begin{tabular}{|c|c|c|c|c|c|c|c|c|c|}
\hline \multirow[t]{2}{*}{ Type of park } & \multirow{2}{*}{$\begin{array}{l}\text { Social } \\
\text { status }\end{array}$} & \multicolumn{2}{|l|}{ First ring } & \multicolumn{2}{|l|}{ Second ring } & \multicolumn{2}{|l|}{ Third ring } & \multirow{2}{*}{$\begin{array}{l}\text { Sum of } \\
\text { population } \\
\text { in three rings }\end{array}$} & \multirow{2}{*}{$\begin{array}{l}\text { Percent of } \\
\text { population } \\
\text { to park access } \\
\text { (three rings) }\end{array}$} \\
\hline & & $\begin{array}{l}\text { Number of } \\
\text { population }\end{array}$ & $\begin{array}{l}\text { Percent of } \\
\text { population to } \\
\text { park access }\end{array}$ & $\begin{array}{l}\text { Number of } \\
\text { population }\end{array}$ & $\begin{array}{l}\text { Percent of } \\
\text { population to } \\
\text { park access }\end{array}$ & $\begin{array}{l}\text { Number of } \\
\text { population }\end{array}$ & $\begin{array}{l}\text { Percent of } \\
\text { population to } \\
\text { park access }\end{array}$ & & \\
\hline \multirow[t]{3}{*}{ City park } & Low & 62,695 & 8.6 & 142,260 & 19.4 & 174,414 & 23.8 & 379,369 & 51.8 \\
\hline & Middle & 37,484 & 6.7 & 183,353 & 33.0 & 197,888 & 35.6 & 418,725 & 75.3 \\
\hline & High & 15,881 & 14.5 & 45,873 & 41.8 & 45,624 & 41.6 & 107,378 & 97.9 \\
\hline \multirow[t]{3}{*}{ Regional park } & Low & 186,693 & 25.5 & 306,931 & 41.9 & 143,933 & 19.7 & 637,557 & 87.0 \\
\hline & Middle & 186,448 & 33.5 & 209,189 & 37.6 & 145,093 & 26.1 & 540,730 & 97.3 \\
\hline & High & 29,937 & 27.3 & 32,712 & 29.8 & 32,699 & 29.8 & 95,348 & 86.9 \\
\hline \multirow{3}{*}{$\begin{array}{l}\text { Community } \\
\text { park }\end{array}$} & Low & 34,413 & 4.7 & 124,254 & 17.0 & 281,794 & 38.5 & 440,461 & 60.1 \\
\hline & Middle & 32,865 & 5.9 & 81,244 & 14.6 & 224,958 & 40.5 & 339,067 & 61.0 \\
\hline & High & 12,965 & 11.8 & 27,884 & 25.4 & 42,983 & 39.2 & 83,832 & 76.4 \\
\hline \multirow{3}{*}{$\begin{array}{l}\text { Neighborhood } \\
\text { park }\end{array}$} & Low & 84,808 & 11.6 & 158,298 & 21.6 & 168,938 & 23.1 & 412,044 & 56.3 \\
\hline & Middle & 83,329 & 15.0 & 197,694 & 35.6 & 209,074 & 37.6 & 490,097 & 88.2 \\
\hline & High & 12,816 & 11.7 & 28,684 & 26.2 & 44,862 & 40.9 & 86,362 & 78.7 \\
\hline \multirow[t]{3}{*}{ Pocket park } & Low & 21,558 & 2.9 & 50,632 & 6.9 & 0 & 0.0 & 72,190 & 9.9 \\
\hline & Middle & 22,160 & 4.0 & 44,842 & 8.1 & 0 & 0.0 & 67,002 & 12.1 \\
\hline & High & 4,010 & 3.7 & 5,312 & 4.8 & 0 & 0.0 & 9,322 & 8.5 \\
\hline
\end{tabular}

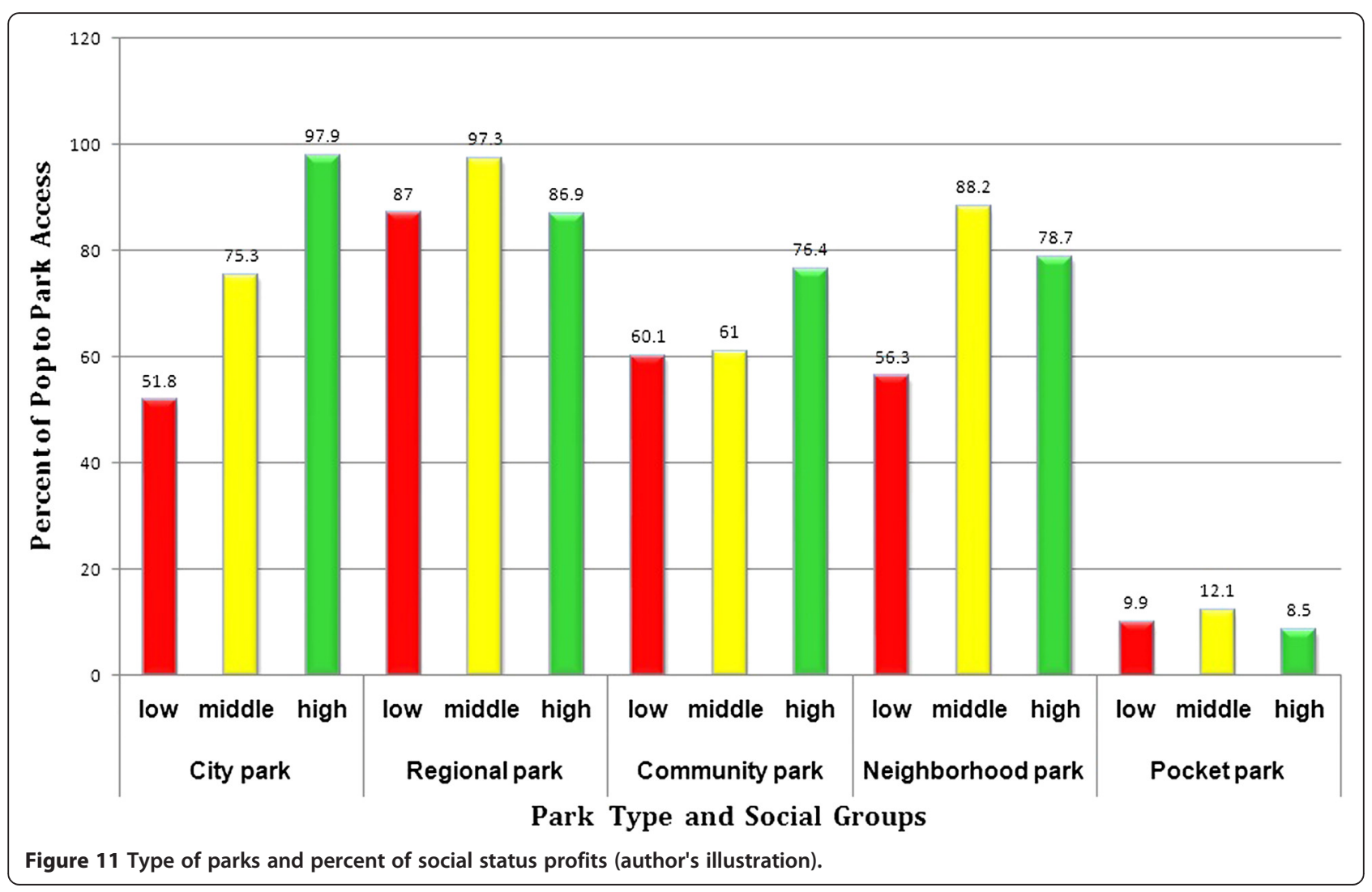


Van Zoest 2004) or accessibility of ethnic and religious groups (Comber et al. 2008) were studied.

Also, we used suitable data (The data used for the social classification are education, occupation, household dimension, income, land value, building type and property sizes, and informal settlement map) for social groups classification and in the first social-economic map for Tabriz produced in this research.

\section{Conclusions}

Green spaces play an important role in supporting urban communities both ecologically and socially. In Tabriz, their importance has been recognized in public policy commitments aiming to ensure ready access to green space for all. We assessed the accessibility of parks for residents and their distribution in Tabriz's city limits. We also examined how green supply services compare between different levels of social status. Many households do not enjoy government recommended levels of access to public green space. The results highlight the social segregation in park distribution and their accessibility in Tabriz. The best parks are located in the high social status areas, and the accessibility is the best among all societal levels. The low social status groups do not have good access to urban parks. The distribution of public parks in Tabriz does not reflect the greater need these groups have due to the lack of their own private urban green-like social groups of high social status have.

Protecting, planning, and building parks in Tabriz with appropriate ecosystem services, amenities, and furnishings, based on established guidelines for green space planning, can resolve the green space shortage and poor accessibility for low social groups.

\section{Competing interests}

The authors declare that they have no competing interests.

\section{Authors' contribution}

All authors read and approved the final manuscript.

\section{Author details}

${ }^{1}$ Research Group for Urban and Landscape Ecology, Department of Geography and Geology, University of Salzburg, Salzburg, Austria. ${ }^{2}$ Department of Landscape Engineering, University of Tabriz, Bolvare 29 Bahman, Tabriz, Iran.

Received: 9 August 2014 Accepted: 13 December 2014

Published online: 13 March 2015

\section{References}

Adimark (2004) Mapa socioeconomic de Chile.Nivelsocioeconómico de los hogaresdelpaísbasadosendatos del Censo. Chile <http://www.adimark.cl/ medios/estudios/mapa_socioeconomico_de_chile.pdf> (Sep. $\left.1^{\text {st }}, 2011\right)$.

Asgharizamani A (2000) Evolution of informal settlement in Iran, case study: Tabriz. In: M.S. thesis. University of Tabriz, Tabriz, Iran

Babaiaghdam F (2007) Analysis of spatial patterns of urban margins. In: Ph.D. thesis. University of Tabriz, Tabriz, Iran

Barbosa O, Tratalos JA, Armsworth PR, Davies RG, Fuller RA, Johnson P, Gaston KJ (2007) Who benefits from access to green space? A case study from Sheffield, UK. Landsc Urban Plann 83:187-195

Bedimo-Rung AL, Mowen AJ, Cohen DA (2005) The significance of parks to physical activity and public health: a conceptual model. Am J Prev Med 28(2S2):159-168
Benson ED, Hansen JL, Schwartz AL Jr, Smersh GT (1998) Pricing residential amenities: The value of a view. J R Estate Finance Econ 16:55-73

Biddulph F (1999) The legacy of schooling: Student teachers' initial mathematical feelings andcompetence. Math Teach Educ Dev 1:64-71

Binford MW, Buchenau MJ (1993) Riparian green ways and water resources. In: Smith DS, Hellmund PC (eds) Ecology of greenways. University of Minnesota Press, Minneapolis, pp 69-104

Bolund P, Hunhammar S (1999) Ecosystem services in urban areas. Ecol Econ 29:293-301

Breuste, J (2003) Grundlagen der Modellierung der urbanen Landschaftsstruktur Anwendung von Methoden der Landschaftsökologie in der stadtökologischen Analyse. In: Schmitt, Thomas (Hrsg.): Themen, Trends und Thesen der Stadt und Landschaftsökologie -Festschrift für Hans-Jürgen Klink. Bochum, S, pp 1-14.

Breuste J, Qureshi S (2011) Urban sustainability, urban ecology and the Society for Urban Ecology (SURE). Urban Ecosyst 14(3):313-317, DOI 10.1007/s11252011-0186-3

Breuste J, Niemela J, Snep RPH (2008) Applying landscape ecological principles in urban environments. Landsc Ecol 23:1139-1142, DOI 10.1007/s10980-008-9273-0

Brown BB, Werner CM, Amburgey JW, Szalay C (2007) Walkable route perceptions and physical features: converging evidence for en route walking experiences. Environ Behav 39:34-61

Cao X, Onishib A, Chen J, Imura H (2010) Quantifying the cool island intensity of urban parks using ASTER and IKONOS data. Landsc Urban Plann 96:224-231

Chiesura A (2004) The role of urban parks for the sustainable city. Landsc Urban Plann 68:129-138

Coles RW, Bussey SC (2000) Urban forest landscapes in the UK- progressing the social agenda. Landsc Urban Plann 52:181-188

Comber A, Brunsdon C, Green E (2008) Using a GIS-based network analysis to determine urban green space accessibility for different ethnic and religious groups. Landsc Urban Plann 86:103-114

Crane P, Kinzig A (2005) Nature in the metropolis. Science 308:1225-11225

Cranz G (1983) The politics ofparkdesign: A history ofurban parks inAmerica. Massachusetts Institute of Technology Press. Massachusetts, Cambridge

Daneshpour ZA, Mahmoodpour A. (2009). Exploring the people's perception of urban public parks in Tehran. REAL CORP 2009: Cities 3.0 , Sitges, 22-25 April 2009 - http://www.corp.at.

De Vries S, Van Zoest J. (2004). The impact of recreational shortages on urban livability. Proceedings of the Open Space-People Space Conference, Edinburgh, Scotland.

Deshpande AD, Baker EA, Lovegreen SL, Brownson RC (2005) Environmental correlates of physical activity among individuals with diabetes in the rural Midwest. Diabetes Care 28:1012-1018

Environment, D.G (2012) The Multifunctionality of Green Infrastructure (March 2012) Science for Environmental Policy In-Depth Report. DG Environment European Commission

EEA (European Environmental Agency) (2011) Green infrastructure and territorial cohesion. The concept of green infrastructure and its integration into policies using monitoring systems. EEA Technical report, 18. European Environment Agency.

Frumkin H (2001) Beyond toxicity: the greening of environmental health. Am J Prev Med 20:47-53

Gaston KJ, Warren PH, Thompson K, Smith RM (2005) Urban domestic gardens (IV): the extent of the resource and its associated features. Biodivers Conserv 14:3327-3349

Geoghegan J, Waingeret LA, Bockstael NE (1997) Spatial landscape indices in a hedonic framework: an ecological economics analysis using GIS. Ecol Econ 23:251-264

Ghorbani R (2009) Assessing Park Deficiency in Tabriz Urban Areas. Soffeh Fall 2008-Winter 2009 17(47):109-123

Gidlof-Gunnarsson A, Ohrstrom E (2007) Noise and well-being in urban residential environments: the potential role of perceived availability to nearby green areas. Landsc Urban Plann 82:115-126

Giles-Corti B, Timperio A, Bull F, Pikora T (2005) Understanding physical activity environmental correlates: increased specificity for ecological models. Exercise and Sport Science Reviews 33:175-181

Gobster PH, Westphal LM (2004) The human dimensions of urban greenways: planning for recreation and related experiences. Landsc Urban Plann 68:147-165

Gómez-Baggethun E, Barton DN. (2012) Classifying and valuing ecosystem services for urban planning. 10.1016/j.ecolecon.2012.08.019, in press.

Grahn P, Stigsdotter U (2003) Landscape planning and stress. Urban Forestry and Urban Greening 2:1-18 
Gutiérrez J (2001) Location, economic potential and daily accessibility: an analysis of the accessibility impact of the high-speed line Madrid-Barcelona-French border. J Transport Geogr 9:229-242

Hami A (2009) User's preferences of usability of urban parks in Tabriz. Tabriz University, Tabriz, Iran

Hami A, Suhardi BM, Manohar M, Shahhosseini H (2001) User's Preferences of Usability and Sustainability of old Urban Park in Tabriz, Iran. Aust J Basic Appl Sci 5(11):1899-1905

Hartig T, Evans GW, Jamner LD, Davis DS, Garling T (2003) Tracking restoration in natural and urban field settings. J Environ Psychol 23:109-123

Hayward DG, Wehitzer WH (1984) The public image of urban parks. Urban Ecol 8:243-268

Heynen N, Perkins HA, Roy P (2006) The political ecology of uneven urban green space: the impact of political economy on race and ethnicity in producing environmental inequality in Milwaukee. Urban Aff Rev 42:3-25

Hillsdon M, Panter J, Foster C, Jones A (2006) The relationship between access and quality of urban green space with population physical activity. Public Health 120:1127-1132

lamtrakul P, Teknomo K, Hokao K (2005) Walking and cycling behavior within the service area of public parks. Journal of the Eastern Asia Society for Transportation Studies 6:225-240

Ignatieva M, Stewart GH, Meurk C (2011) Planning and design of ecological networks in urban areas. Landsc Ecol Eng 7:17-25

Imai H, Nakashizuka T (2010) Environmental factors affecting the composition and diversity of avian community in mid to late breeding season in urban parks and green spaces. Landsc Urban Plann 96:183-194

Iranian statistical organization (2005) Census of Population and Housing. Statistical Organization Press, Tehran

Kaczynski A, Henderson KA (2007) Environmental correlates of physical activity: A review of evidence about parks and recreation. Leisure Science 29:315-354

Kahn PH (1999) The Human Relationship with Nature: Development and Culture. MIT Press, Cambridge, MA

Kaplan R, Kaplan S (1989) The experience of nature: A psychological perspective. Cambridge University Press, Cambridge, UK

Kessel A, Green J, Pinder P, Wilkinson P, Grundy C, Lachowycz K (2009) Multidisciplinary research in public health: A case study of research on access to green space. Public Health 123(1):32-38

Khosravaninezhad S, Abaszadeh Z, Karimzadeh F, Zadehbagheri P. (2011). Parks and an Analysis of their Role in Improving the Quality of Urban Life, Using Seeking-Escaping Model, Case Study: Tehran Urban Parks. REAL CORP 2011, CHANGE FOR STABILITY, Lifecycles of Cities and Regions,18-20 May 2011, Essen. http://www.corp.at.

Kordowski K, Kuttler W (2010) Carbon dioxide fluxes over an urban park area. Atmos Environ 44:2722-2730

Korpela K, Yle'n M (2007) Perceived health is associated with visiting natural favorite places in the vicinity. Health Place 13:138-151

Korpela KM, Hartig T, Kaiser F, Fuhrer U (2001) Restorative experience and selfregulation in favourite places. Environ Behav 33:572-589

Kuo FE, Sullivan WC. (2001) Aggression and violence in the inner city: Impacts of environment and mental fatigue. Environ Behav 33(4).

Lau JCY, Chiu CCH (2003) Accessibility of low-income workers in Hong Kong. Cities 20(3):197-204

Lindsey G, Maraj M, Kuan S (2001) Access, equity, and urban greenways: An exploratory investigation. Prof Geogr 53(3):332-346

Maas J, Verheij RA, Spreeuwenberg P, Groenewegen PP (2008) Physical activity as a possible mechanism behind the relationship between green space and health: a multilevel analysis. BMC Public Health 8:206

Majnonian H (1996) Parks, Green Spaces, and Promenades. Parks and Green Spaces Org press, Tehran

Morancho AB (2003) A hedonic valuation of urban green areas. Landsc Urban Plann 66:35-41

More T, Payne B (1978) Affective responses to natural areas near cities. J Leisure Res 10:7-12

Municipality of Tabriz (2012) Detailed project reports of Tabriz. Municipality of Tabriz Press, Tabriz

Nielsen TS, Hansen KB (2007) Do green areas affect health? Results from a Danish survey on the use of green areas and health indicators. Health and Place 13:839-850

Nohorly D (1999) Economic Evaluation of El Gohi Park in Tabriz. Tehran University, Tehran, Iran

Oh K, Jeong S (2007) Assessing the spatial distribution of urban parks using GIS Landsc Urban Plann 82:25-32
Panahi JG (2000) Analyzing of urbanization process in Iranian metropolitans, case study: Tabriz. In: M.S. thesis. University of Tabriz, Tabriz, Iran

Pauleit S, Ennos R, Golding Y (2005) Modeling the environmental impacts of urban land use and land cover change-a study in Merseyside, UK. Landsc Urban Plann 71:295-310

Payne L, Orsega-Smith E, Roy M, Godbey G (2005) Local park use and personal health among older adults: an exploratory study. Journal of Park and Recreation Administration 23:1-20

Peters K, Elands B, Buijis A (2010) Social interactions in urban parks: Stimulating social cohesion? Urban Forestry and Urban Greening 9:93-100

Pickett STA, Cadenasso ML, Grove JM, Nilon CH, Pouyat RV, Zipperer WC, Costanza R (2001) Urban ecological systems: linking terrestrial ecological, physical, and socioeconomic components of metropolitan areas. Annu Rev Ecol Systemat 32:127-157

Potwarka LR, Kaczynski AT, Flack AL (2008) Places to play: association of park space and facilities with healthy weight status among children. J Community Health 33:344-350

Pretty J, Peacock J, Hine R (2006) Green exercise: the benefits of activities in green places. Biologist 53:143-148

Public Health Office Copenhagen (2006) SundeKøbenhavn e reiallealdreKøbenhavnsKommunesSundhedspolitik 2006-2010.Healthy Copenhageners in all ages - Health policy of the Municipality of Copenhagen for 2006-2010.Municipality of Copenhagen, <www. folkesundhed.kk.dk/media/folkesundhedkbh/Politikkerogstrategier/ sundhedspolitik_kk.pdf.ash $x>\left(J u l .6^{\text {th }}, 2009\right)$

Qureshi S, Breuste JH, Lindley SJ (2010) Green space functionality along an urban gradient in Karachi Pakistan: A socio-ecological study. Human Ecol 38(2):283-294, Doi: 10.1007/s10745-010-9303-9

Rahimi A (2013) Assessment and modeling of spatial development, with the emphasis on infill development: the case of Metropolis Tabriz. Tabriz University, Tabriz, Iran

Romero H, Vásqueza A, Fuentesa C, Salgadoa M, Schmidt A, Banzhaf E (2012) Assessing urban environmental segregation (UES). The case of Santiago de Chile. Ecol Indicat 23:76-87

Saidnia A (2004) Urban green space. Green book of municipality Press (5), Iran

Salazar S, Menéndez L (2007) Estimating the nonmarket Benefits of an Urban Park: does proximity matter? Land Use Policy 24:296-305

Schetke S, Haase D, Breuste J (2010) Green space functionality under conditions of uneven urban land use development. J Land Use Sci 5(2):143-158

Smith RM, Gaston KJ, Warren PH, Thompson K (2005) Urban domestic gardens (V): relationships between landcover composition, housing and landscape. Landsc Ecol 20:235-253

Stanners D, Bourdeau P (1995) The urban environment. In: Stannersand D, Bourdeau P (eds) Europe's Environment: The Dob r I s Assessment. European Environment Agency, Copenhagen, pp 261-296

Sugiyama T, Leslie E, Giles-Corti B, Owen N (2008) Associations of neighborhood greenness with physical and mental health: do walking, social coherence and local social interaction explain the relationships? J Epidemiol Community Health 62:e9

Talen E, Anselin L (1998) Assessing spatial equity: an evaluation of measures of accessibility to public playgrounds. Environment and Planning A 30:595-613

TEEB (The Economics of Ecosystems and Biodiversity) (2011) Manual for Cities: Ecosystem Services in Urban Management. UNEP and the European Commission, Earthscan, London

Tsou K, Hung Y, Chang Y (2005) An accessibility-based integrated measure of relative spatial equity in urban public facilities. Cities 22(6):424-435

Tyrväinen $L$ (1997) The amenity value of the urban forest: an application of the hedonic pricing method. Landsc Urban Plann 37:211-222

Ulrich RS (1984) View through a window may influence recovery from surgery. Science 224:420-421

Ulrich RS, Simons RF, Losito BD, Fiorito E, Miles MA, Zelson M (1991) Stress recovery during exposure to natural and urban environments. J Environ Psychol 11:201-230

Van den Berg AE, Hartig T, Staats H (2007) Preference for nature in urbanized societies: stress, restoration, and the pursuit of sustainability. J Soc Issues 63(1):79-96

Van Herzele A, Wiedemann T (2003) A monitoring tool for the provision of accessible and attractive urban green spaces. Landsc Urban Plann 63:109-126

Weiland U, Kindler A, Banzhaf E, Ebert A, Reyes-Paecke S (2011) Indicators for sustainable land use management in Santiago de Chile. Ecol Indicat 11 (5):1074-1083

Zista Consulting Engineers (2005) Informal settlement in Tabriz. Housing and Urban planning Organization Press, Tabriz 